\title{
Internal and External Monitoring of Village Allocation Funds(Budget Year of 2015-2016 in Bogor Regency, West Java Province)
}

\author{
Rizka Dwi Pratiwi ${ }^{1}$, Achmad Lutfi ${ }^{1}$ \\ \{Rizkadwipratiwi29@gmail.com $\left.{ }^{1}\right\}$ \\ Universitas Indonesia, Depok, Indonesia ${ }^{1}$
}

\begin{abstract}
This study describes the internal and external monitoring process of village allocation funds sourced from APBN in Bogor Regency, West Java Province and factors influencing internal and external monitoring of village allocation funds in Bogor Regency. Theories used by internal supervision are the supervision process and external supervision theory that is transparency, accountability and participation. The research approach is post-positivism. Techniques of library research data collection and in-depth interviews. The result of the internal supervision process of Inspectorate of Bogor Regency has not been optimal because it is generally implemented in the village government supervision activity through the Annual Working Program (PKPT) for 5 rounds in one year. Special supervision on village allocation funds has not been implemented in 2015-2016. Factors affecting the internal control of the Inspectorate of Bogor Regency are the changes of the village government structure, the political elements, the human resources of the village apparatus, the quantity of Human Resources Inspectorate and the area of supervision. The process of external supervision with the concept of transparency, accountability and participation has not been optimally affected by clarity, that has not been distributed, access to receive documents, accountability is still weak and active involvement in community participation has not been optimal.
\end{abstract}

Keywords: Monitoring, Internal Monitoring, External Monitoring, Village funds

\section{Introduction}

Regional autonomy was a concrete form of central government distribution affairs and local government as the principle of decentralization which was marked by the delegation of some authorities, responsibilities, and resources from higher to lower level of government. Fiscal decentralization according to Djaenuri [1] the delegation of central government authority to local government. Village was the smallest unit in a country, the importance of development in village as a part of efforts to support the unity of legal community based on the special rights of origin as a definition from the village [2]. The attention form of President Joko Widodo about NAWACITA which was to build Indonesia from villages by the existence of regulation UU No. 6 Year 2014 about Village. Not only regulation, but the next governmental attention with the holding of Village's Fund Program from APBN, the distribution process of village's fund between 2015-2016 also had some changes, which was 
in 2015 consisted of 3 steps and 2016 consisted of 2 steps. West Java Province was a province close to the capital city, according to the Minister of Home Affairs Tjahjo Kumolo that West Java had many superiorities than other provinces, such as culture diversity, most tourism destination, capital city, manufacturing industry activities and national strategies, national vital installation in education, LITBANG and HANKAM, not only that, according to the contribution data of West Java to national PDB of 14,33\%. Foreign investment of $34,46 \%$, and also PDB contribution of manufacturing industry sectors of $60 \%$ [3]. West Java province was one of the other provinces which collected most fund from villages and increased from 2015 to 2016, which was Rp. 1.589.711.596 and Rp. 3.568.437.985. The large portion of village's fund in West Java, Regency of Bogor was the regency with most villages, 417 villages obtained fund for:

Table 1. Village's Fund in 2015 and 2016

\begin{tabular}{|c|c|c|}
\hline No. & Village's Fund (Year) & $\begin{array}{c}\text { Village's Fund (in } \\
\text { thousand rupiah) }\end{array}$ \\
\hline 1 & Village's Fund in 2015 & 130.262 .061 \\
\hline 2 & Village's Fund in 2016 & 292.555 .382 \\
\hline
\end{tabular}

The absorption of village's fund, especially in Regency of Bogor got appreciation by the Village Minister Marwan Jafar which said that the absorption of village's fund in Regency of Bogor went well and 100\% realized for 417 villages which had utilized village's fund maximally [4]. In reality, that maximal absorption had not been supported by the readiness of human resources in the level of village government because there were some problems about the village's fund that was not right on target due to village's APB, inaccuracy of road infrastructure project targeting that was done not in the land owned by the village, not transparent budget, uninvolved community, BPD in village's deliberations, unreported LPJ village fund management, minimal information of village apparatus community. The problems occurred in the village's fund required supervision activity so that the village's fund would go optimally, village's fund supervision involved stakeholders not only in central government, local government, but also village government as regulated in UU No. 6 Year 2014 about Village, which was Article 55 that discussed about the function of BDP, Article 68, Article 82, and Article 94 that clarified supervision by the society and village institutions, Article 113 discussed about the guidance and supervision by the central government, Article 114 by provincial government, and Article 115 by the regency/city government. Based on the problems about village's fund, which was the lack of knowledge of village government apparatus in using village's fund, unqualified village governmental apparatus in administrative aspect, the main problem raised by the researcher, which was: "How was the implementation of internal and external supervision on the village fund?" and "What were the factors that affected internal and external supervision of village's fund? The research aimed to describe the supervision and factors that affected internal and external supervision of village's fund.

This research used the theory from Griffin [5], Robbins and Coulter [6] about the supervision process used for internal stakeholders that were consisted of 4 dimensions, such as the process of setting standard that consisted of information about the supervised object, the purpose of supervision, the strategy of supervision, the availability of plan in work coordination, resources or supporting facilities of supervision, and the availability of schedule of supervision. The process dimension of measurement was consisted of the interaction with subordinates, the opportunity to exchange information, the existence of statistical reports (graphic, table, diagram), the conference, the agenda to hold meeting, the one-on-one 
conversation, the conversation by telephone media, and the written report. The process dimension of comparing was consisted of range variation indicator, and comparing written report with factual condition and process dimension of corrective action was consisted of maintaining status quo, doing nothing, do strategy changes, do structure changes, providing training program, redesigning job description, dismissing employees, revising standard, increasing employees number, and giving direction, the theory of internal supervision factors by Munandar [7] which was consisted of organization environment changes factors, organization complexity improvement, and necessity in delegating authority. The theory of Pan Suk Kim [8] about transparency that was consisted of Clarity that was consisted of information indicator given could be understood, accessible, comprehensive, without hidden meaning, explained information (the usage of jargon was minimalized), and document to clarify information, integration dimension was consisted of the information conveyed through detailed index, the availability of additional information reference about the Village's Fund, the availability of Village's Fund explanation with the activities or other programs and additional information metadata village's fund with electronic content, the availability of room for the society to ask for documents, the village government helped the society to find information, the village government provided assistance for the society to understand information and dialog opportunity between village government and the society, and logic/rational was consisted of society could join village's fund planning, the society could monitor village's fund decision continuously, the society involvement to monitor village's fund decision, clear, rational, standardized, formal, flexible, and information about village's fund was scientific, Quick \& Bryson [9] participation dimension was consisted of two indicators, which were society involvement in forming village's fund, and the society involvement in implementing Arnstein desadan fund [10] about the ladder of community participation, and theory from LAN and BPKP [11] about the accountability used for external stakeholders that was consisted of intentions disclosure that was consisted of outcomes result delivery (benefit, justice, and equity) to the society, directing mind visibility dimension that was consisted of opportunity indicator of directing mind from villages' fund to the society through report, performance visibility dimension which was consisted of the village government to express actual performance to the society, answering for precaution taken dimension that was consisted of providing information to the society about village's fund risk, governing body and citizen responsibility that was consisted of the efforts to increase the equity and responsibility, reciprocal accountability dimension that was consisted of accountability submission indicator from the government to the society, and the reciprocity from the accountability, the balance of power dimension, duties, and accountability that was consisted of the balance of power, duties, and accountability, and also the hope to overcome obstacles, corporate fairness dimension which was consisted of responsibility availability indicator if conflict of interest happened, right roles dimension that was consisted of indicator from the government who gave responsibility and reason to the society, citizen caution dimension that was consisted of active society involvement indicator, wage of abdications dimension that was consisted of the indicators that followed up authority misusage, the opportunity for the citizens to orientate, the availability of public appraisal, and the efforts to identify deviation, and validation of assertions dimension that was consisted of public accountability indicator that was supported by practitioner or researcher. 


\section{Method}

This research used post positivisty according to Neuman [12], "Organized method for combining deductive logic with precise empirical observations of individual behavior in order to discover and confirm a set of probabilistic casual laws that can be used to predict general patterns of human activity" which was post positivist as organization in combining deductive thinking with empirical observation from the individual habits to research and also confirm a series of causal relationship probabilities to predict pattern from human activities. Based on the research purpose [12] which was, "Descriptive research focuses on "how" and "who" questions how did it happen?" "who is involved?" to describe social phenomenon about how was the process of village's fund supervision by the stakeholders in Regency of Bogor and also the factors that affect village's fund supervision. The research purpose for pure research which was for the researcher necessity [12]. Based on the time dimension which was cross sectional, was a research done in a certain time to see an event [12]. The data collection technique used was literature research and in-dept interview about secondary data and primary data [13]. The informant in this research were Staff Director of Community Empowerment Director, Directorate General of Development and Empowerment of Village Community, Ministry of Village, Development of Disadvantaged Regions and Transmigration Sub Division Program and Reporting Inspectorate Bogor Regency, Sadeng Village, Muarajaya, Bantarkuning, Cintamanik, Banjarwaru and Cileungsi, BPD Desa Sadeng, Muarajaya, Bantarkuning, Cintamanik, Banjarwaru and Cileungsi, community leaders Sadeng Village, Bantarkuning, Cintamanik, Banjarwaru and Cileungsi and LSM Orbit Archipelago Regency of Bogor. The data analysis technique used according to [14]. Illustrative Method would put theoretical concept into empty blank later, would be filled by empirical evidences obtained.

\section{Result and Discussion}

The research result of information availability in Inspectorate Regency of Bogor about village's fund supervision was as follow : The information about objects especially this village's fund was related to village government specifically for 2015-2016, we only supervised village's fund generally because it was included in village government supervision activities (interview with Mr. Nurjen, 19th June 2017).

The next result was the purpose of village's fund supervision purpose ensured that wether the village's fund had been used properly and that village's fund was one of them because in 2015-2016 we didn't supervise village's fund specifically, but the real purpose of that village's fund supervision purpose was for us, which was to provide a good assurance that the village's fund supervision was done based on the regulation, specifically about the exact location, right on target, right channel, exact number, and exact usage (interview with $\mathrm{Mr}$. Nurjen, 19th June 2017). Inspectorate of Regency of Bogor did not have supervision strategy, supervision strategy was not needed because supervision activity had been scheduled, which was held in the third week of January until the fourth week of April. The Inspectorate's work plan was carried out in coordination with the village. The Inspectorate of Bogor Regency was less than personal side although it had the highest number of Inspectorate apparatuses in West Java Province. The quantity of Human Resource Inspectorate of Bogor Regency were 98 people. The results in Bogor Regency Inspectorate carried out coordination of village government in the village's fund at the time of field trip, the availability of graphic information and diagrams were not owned only the availability of tables related to the implementation schedule of supervision, the Inspectorate of Bogor Regency did not conduct 
conference activities because the supervisory information was confidentially submitted to the regional head. At the supervision of village's funds by the Inspectorate of Bogor Regency available reports on the results of the inspection and Performance Report of Government Institution (LAKIP) Inspectorate of Bogor Regency. Inspectorate of Bogor Regency should be guided by regulation in implementing supervision, namely Law Number 6 Year 2014 on Village (State Gazette of the Republic of Indonesia Year 2014 Number 7, Supplement to State Gazette of the Republic of Indonesia Number 5495), Regulation of the Minister of Home Affairs Number 78 Year 2014 on Coaching Policy and Supervision within the Ministry of Home Affairs and Local Governments Year 20115 (State Gazette of the Republic of Indonesia Year 2014 Number 1745), and Decision of Bogor Regency Number 700/15 / Kpts / Per-UU / 2015 on Annual Inspection Work Program Inspectorate Bogor Regency 2015. Subsequent research that Inspectorate of Bogor Regency provided recommendations when it found error or acts of irregularities by the village government. An example of a follow-up by the Inspectorate if the following error was found:

Table 2. The Follow-up on Periodic Examination Result ofCiawi Sub-District 2015

\begin{tabular}{|c|c|c|c|c|c|c|c|c|c|c|c|c|}
\hline \multirow[t]{2}{*}{$x_{0}$} & \multirow{2}{*}{$\begin{array}{l}\text { Vlape } \\
\text { Nomt }\end{array}$} & \multirow{2}{*}{$\begin{array}{c}\text { Renct of } \\
\text { Frat }\end{array}$} & \multirow{2}{*}{ 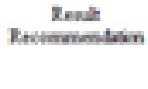 } & & & & \multicolumn{6}{|c|}{ Whan } \\
\hline & & & & Thath & $\stackrel{\text { In }}{\text { pregen }}$ & Sist & hweanises & \multicolumn{4}{|c|}{ Denam } & \\
\hline 1 & 2 & 3 & 4 & 5 & 4 & 9 & $t$ & 9 & $w$ & 11 & 12 & 13 \\
\hline 1 & $\begin{array}{l}\text { Clemping } \\
\text { Vuape }\end{array}$ & 4 & 6 & 6 & 0 & 0 & 10,060000 & & \multicolumn{3}{|c|}{$2073.100,00$} & $2013.100,00$ \\
\hline
\end{tabular}

Source: The Title Book of Supervision, 2015.

In the example table above, the Inspectorate found the number of findings as much as 4 and provided recommendations for the completion of the findings as much as 6 . About the findings, Bogor District Inspectorate had the function, mission, and task which was to create professional inspectorate in realizing the governance of Bogor regency in Indonesia. The Inspectorate never made structural changes to the village administration and the organization of the inspection activities carried out:

The examination that we formed a team consisting of the responsible person in charge of the technical controller of the team leader and the team member that was the structure within the supervisory organization. The person in charge was of course held by the inspector, the responsible representative was held by the secretary, the technical controller was IRBAN that had been certified, team leader was also the same that was the auditor who already had the certificate of team leader and team member (interview with Mr. Nurjen, 19th June, 2017).

Inspectorate of Bogor Regency in conducting inspection conducted by related positions in inspection duty. Reward Inspectorate related to honor and punishment related to internal warning if not yet submit report of inspection result. The specific training on village's fund had not been implemented only in the form of general training such as SP Jan, the village government did not change the structure of the village government due to the authority of the village head, the public complaint as one of the Inspectorate's report in supervising, in 20152016 the Inspectorate of Bogor Regency increased the number of auditor personnel. The organizational structure of the village, as well as the change of leadership of the village head, gave an influence on the supervision by the Inspectorate of Bogor Regency, PKPT as a reference in conducting the supervisory activities, the crosscheck validity of the data on the reports was ensured by the Inspectorate to ensure the quality of supervision quality in order to avoid misunderstanding, different village government apparatus became obstacles for Inspectorate of Bogor Regency, performance report as administrative examination material, village fund practice still constrained by incompetence of village government apparatus. 
The resulting research in Sadeng Village, village fund information was understood by the community and village government officials. In Desa Muarajaya the information was not understood at first, in the village of Bantarkuning the village government and the community had not understood the village fund yet, in Desa Cintamanik the community had not yet been informed, in Banjarwaru Village information was not understood due to lack of socialization, and in Cileungsi Village information was understood. Access to community information in Sadeng Village could be done by visiting the village office, coordinated with LPM / BPD, in Muarajaya Village using project boards, availability of meetings held every 3 months 1 times, in Bantarkuning Village held with meetings, MUSRENBANGDES meeting, MUSDUS, in Cintamanik Village no access to information, access information in Banjarwaru Village during the recitation, RT / RW meeting, community access could be obtained through a paper flyer on display at the strategic point of the village. as shown below:

Table 3. Leaflet Procurement Of Cileungsi Village's Fund In 2016

\begin{tabular}{|c|c|c|c|c|c|c|c|}
\hline \multirow[t]{2}{*}{ No } & \multirow[t]{2}{*}{ Activity } & \multirow[t]{2}{*}{ Volume } & \multicolumn{3}{|c|}{ Location } & \multirow[t]{2}{*}{ Cost } & \multirow[t]{2}{*}{ implementation } \\
\hline & & & Sub-district & RT & $\mathrm{RW}$ & & \\
\hline 1 & Impos Street & $700 \mathrm{M} \times 2,5 \mathrm{M}$ & Inpos & $01-02$ & 01 & 110.000 .000 & August \\
\hline 2 & Loji Street & $700 \mathrm{M} \mathrm{x} \mathrm{2,5 \textrm {M }}$ & Loii & $01-10$ & 02 & 110.000 .000 & Masy \\
\hline 3 & $\begin{array}{l}\text { Retaining wall } \\
\text { of Loiji } \\
\text { Village }\end{array}$ & $\begin{array}{c}30 \mathrm{Mx} \times 3,5 \mathrm{Mx} \\
0,3 \mathrm{M}\end{array}$ & Loii & 01 & 02 & 30.000 .000 & May \\
\hline 4 & $\begin{array}{l}\text { Retaining wall } \\
\text { of } \\
\text { neighbourhoo } \\
\text { d loji village }\end{array}$ & $100 \mathrm{M} \times 7 \mathrm{M}$ & Loji & 08 & 02 & 100.000 .000 & August \\
\hline 5 & $\begin{array}{l}\text { Maswar } \\
\text { Matemal \& } \\
\text { Child Health } \\
\text { Centre. }\end{array}$ & $4 \mathrm{M} \times 5 \mathrm{M}$ & Loji & 04 & 02 & 20.000 .000 & May \\
\hline 6 & Drainage & $150 \mathrm{M} \mathrm{x} \mathrm{0,3 \textrm {M }}$ & Loiji & 03 & 02 & 7.000 .000 & May \\
\hline 7 & Brigda & $\begin{array}{l}\mathrm{P}=17 \mathrm{ML}= \\
1,2 \mathrm{MT}=7 \mathrm{M}\end{array}$ & Cileungsi & 01 & 03 & 50.000 .000 & May \\
\hline 8 & Pipeline & $1000 \mathrm{M}$ & Cileingai & 02 & 03 & 10.000 .000 & May \\
\hline 9 & Drainage & $100 \mathrm{M} \times 0,2 \mathrm{M}$ & Cilemungsi & 02 & 03 & 5.000 .000 & August \\
\hline 10 & $\begin{array}{l}\text { Environmenta } \\
1 \mathrm{rosd}\end{array}$ & $75 \mathrm{M} \times 1 \mathrm{M}$ & Cilenugai & 04 & 03 & 5.000 .000 & August \\
\hline 11 & $\begin{array}{l}\text { Retaining wall } \\
\text { of Cilinugingi } \\
\text { Village }\end{array}$ & $25 \mathrm{M} \times 3 \mathrm{M}$ & Cilenugsi & 06 & 03 & 30.000 .000 & August \\
\hline 12 & $\begin{array}{c}\text { Public } \\
\text { bathing, } \\
\text { washing, and } \\
\text { toilet (MCK) } \\
\text { facilitios. }\end{array}$ & $3 \mathrm{Mx} 4 \mathrm{M}$ & Cipsok & 03 & 04 & 10.000 .000 & May \\
\hline 13 & Drainage & $150 \mathrm{M} \times 0,3 \mathrm{M}$ & Cipsok & 05 & 04 & 5.000 .000 & May \\
\hline 14 & $\begin{array}{l}\text { Retaining of } \\
\text { environment } \\
\text { street of } \\
\text { Ciherang } \\
\text { Ceads }\end{array}$ & $50 \mathrm{M} \times 6 \mathrm{M}$ & Ciherang Gode & 02 & 05 & 100.000 .000 & May \\
\hline 15 & $\begin{array}{c}\text { environmental } \\
\text { rosd } \\
\text { conconance }\end{array}$ & $150 \mathrm{M} \times 1 \mathrm{M}$ & Cihereng Giade & 03 & 05 & 10.000 .000 & May \\
\hline
\end{tabular}

Source: Government Activities Plan of Cileungsi Village, 2016

Nominal budget and location of the development point was the information submitted to all villages. The nominal village's fund budget were as follows: 
Table 4. Budget of Sadeng Village's Fund, Muarajaya, Bantarkuning, Cintamanik, Banjarwaru And Cileungsi

\begin{tabular}{|c|l|c|c|}
\hline No & \multicolumn{1}{|c|}{ Village } & \multicolumn{1}{c|}{$\begin{array}{c}\text { Year } \\
2015\end{array}$} & $\begin{array}{c}\text { Year } \\
2016\end{array}$ \\
\hline 1 & Sadeng & Rp. 300.010 .656 & Rp. 647.750 .655 \\
\hline 2 & Muarajaya & Rp. 296.655 .617 & Rp. 633.194 .725 \\
\hline 3 & Bantarkuning & Rp. 300.010 .656 & Rp. 647.750 .655 \\
\hline 4 & Cintamanik & Rp. 338.192 .353 & Rp. 813.898 .212 \\
\hline 5 & Banjarwanu & Rp. 303.086 .320 & Rp. 661.134 .403 \\
\hline 6 & Cileungsi & Rp. 308.312 .657 & Rp. 683.876 .792 \\
\hline
\end{tabular}

Source: processed by the researcher, 2017.

Based on the result research in all villages, there was no hidden meaning in all villages, information on village funds used abbreviations in all villages related to DD, BUMDES, ADD, and SORGA DESA. the result research in Sadeng Village documents available RPJMDES and APBDes, in Muarajaya SPJ Village and APBDes, in Bantarkuning Village not available any documents, in Cintamanik Village documents available related to SPJ and APBDes, availability of documents in Banjarwaru Village related to APBDES and Government Performance Report (LKP), as well as in Desa Cileungsi availability of village fund development reports. Additional information on village funding was delivered in Sadeng Village to RT / RW at meetings, in Bantarkuning Village delivered via LPM, additional information in Bantarkuning village related to the use of village funds had similarities with in Desa Cintamanik, additional information in the village of BAnjarwaru related to the change of location of the development had not been implemented because the news of the change event (BAP) was not submitted, the additional information in Cileungsi Village was submitted through musywarah, BPD, LPM, RT / RW. The linkage of village funds to Sadeng Village was related to other sources of village funding in line with what happened in Muarajaya village, in Bantarkuning Village, other village funding sources related to RPJMDes and RKP, in Cintamanik village funds related to village development, village RKP had relationship with RKP, in Cileungsi Village associated with RPJMDes. The result research in Sadeng Village metadata information submitted only to BPD and community leaders it was in harmony with the Muarajaya Village, Bantarkuning Village, Cintamanik and Cileungsi information submitted in the group messenger but not all people could access the information, in Banjarwaru Village electronic content was not yet available. Space for the community to request documents available to all villages through village government, but in Muarajaya village it would be reviewed first, in Banjarwaru Village could be requested to Village BPD, Cileungsi Village could be requested through village government and BPD. The result research on all villages of the community for receiving the documents in Sadeng Village were delivered only verbally, in Muarajaya Village through information board, in Muarajaya village there was no room for the people to receive the document in line with what happened in Desa Cintamanik and Banjarwaru. In Cileungsi Village there is a leaflet document to the public. The results showed that access to information could be found in MUSDES or village meetings in Sadeng Village, Bantarkuning, Cintamanik, information boards at Muarajaya Village, meeting and coordination with TPK in Banjarwaru Village, access to information through RT / RW in Cileungsi Village.

The results of research showed that in 6 villages that became the research of understanding of information about nominal and development. In Sadeng Village the results showed that the village government could carry out dialogue with the community through BPD, TPK, and MUSDES forums in line with what happened in Muarajaya village, Cintamanik, Banjarwaru 
and Cileungsi. In contrast to what happened in Bantarkuning Village based on the results of research dialogue conducted on agricultural socialization activities. The results of the research showed that the monitoring of decisions could be made through BPD, TPK, RT / RW. The MUSDES Forum was a place for people to organize decisions on village funds. the results research showed that in Sadeng Village the clarity of information on village funds was constrained by language, in Muarajaya village the information was felt quite complicated to be understood by village government officials, in Bantarkuning Village and Cintamanik clarity of information related to nominal budget, clarity of information had not happened in Banjarwaru Village for year 2015-2016, unclear information occured in Cileungsi Village in 2015. Associated with the following development information comparing development tables in 6 villages:

Table 5. Comparasion of Development Between 2015-2016

\begin{tabular}{c|c|c|c|} 
No & Village & 2015 & 2016 \\
\hline 1 & Sadeng Village & 17 development & 21 development \\
\hline 2 & Muarajaya Village & 7 development & 25 development \\
\hline 3 & Bantarkuning Village & 15 development & 13 development \\
\hline 4 & Cintamanik Village & 5 development & 2 development \\
\hline 5 & Banjarwaru Village & 14 development & 13 development \\
\hline 6 & Cileungsi Village & 28 development & 15 development \\
\hline
\end{tabular}

Source : processed by the researcher, 2017

The standardization of information in Sadeng Village was implemented with the support of the regulation of Sadeng Village Regulation No. 09 of 2015 on the report on the realization of the implementation of budget revenues and budget expenditure of 2015 and Sadeng village regulation number: 09 year 2016 regarding the responsibility of realization of budget revenues and budget expenditure of 2016 In Muarajaya Village supported by village regulation in Muarajaya Village that was Village Regulation Number 1 Year 2015 about APBDes of budget year 2015 which passed on 5 May 2015, Village Regulation Number 3 Year 2015 about Working Plan of Village Government (RKP Desa) October 2015, Village Regulation No. 1 of 2016 on APBDes 2016 fiscal year endorsed on 24 October 2016 and Village Regulation No. 3 of 2016 concerning Village Government Work Plan (RKP Desa) adopted on 14 November 2016. In Bantarkuning Village on Village Regulation (PERDES) number 02 PERDES 201 (APBDES) in the first semester of 2015, Village Regulation of Bantarkuning number 07 of 2015 on revenue and expenditure budget (APBDES) (APBDES) for fiscal year 2016, Village Regulation of Bantarkuning number 03 year 2016 regarding report of responsibility of realization of budget of revenues and expenditure of village (APBDES) first semester of budget year 2016, Village Regulation of Bantarkuning Number 01 year 2017 about accountability report realization budget of village income and expenditure (APBDES) in second semester of budget year 2016. In Cintamanik Village there were some regulation that was Village Regulation Cintamanik Number 141.1 / I / Year 2015 and Village Regulation Cintamanik Number 1 Year 2016 .. In Banjarwaru Village related to village fund in 20152016 arranged in Village Head of Banjarwaru Regulation Number 05 Year 2015 and Year 2016 on Village Head Report. In Cileungsi Village the availability of Cileungsi Village Regulation No. 2 of 2015 on Village Revenue and Expenditure Budget and Cileungsi Village Regulation No. 4 of 2016 on Village Revenue Expenditure Budget. The result research showed that in Sadeng Village government officials used uniforms and standard language in conveying information to the community, in Muarajaya Village was is not implemented 
because people already knew the village government apparatus, in Bantarkuning Village, Cintamanik, Banjarwaru and Cileungsi government using uniform and ID card. Information on Sadeng Village, Muarajaya, Bantarkuning, Cintamanik and Cileungsi flexible could be accessed anytime different from that happening in Banjarwaru Village that the research results showed that inflexible information in 2015 and BPD Banjarwaru new active in 2016 and in 2015 had a vacuum. In the research results, the presence of village's fund in Sadeng Village, Bantarkuning, Cintamanik, Banjarwaru and Cileungsi made people become more active and critical. In village Muarajaya village government officials had not understood the village funds and the village of Bantarkuning the education to the community.

The results of subsequent research that community involvement in the formulation of village's fund in 6 villages could be implemented by following the activities of MUSDUS, MUSDES, and MUSRENBANGDES. Different results of community involvement in the formulation of the results in Sadeng Village. There were informal meetings activities, in the village of Bantarkuning the availability of weekly meetings, monthly and pengajian. Banjarwaru research results showed that access community involved in the formulation was still minimal for 2015-2016. In Cileungsi Village policy formulation involved the community with the availability of coordination meetings in the region. The research results showed that in Sadeng Village the implementation of village funds was implemented by RT / RW conducted by LPM which was converted as TPK as well as the existence of self-supporting community in the provision of consumption. Results in Muarajaya Village, implementation was implemented by TPK totaling 7 people. In Bantarkuning village implemented by TPK and community involvement of 3-4 people, the results of research in Banjarwaru Village that the involvement of the community as TPK was still minimal and difficult. In Cileungsi Village community involvement as TPK.

The results showed that the benefits of village funds in terms of implementation of development as in Sadeng Village the benefits in the construction of MCK. The results of research on Muarajaya Village, Bantarkuning, Cintamanik, and Cileungsi were the benefits in development on the needs of the region. In Cintamanik Village the benefits were viewed from the access to health, agriculture, and development. Related to fairness and justice it was normative in 6 villages in Sadeng Village in terms of priority scale, Muarajaya Village involving the community, the village of Bantarkuning the submission of a written report, in the village of Cintamanik in terms of development, the village of Banjarawaru inequity appearance-related development, Cileungsi information to the public. the submission of accountability reports was carried out in Sadeng, Muarajaya and Cileungsi Villages, in contrast to Bantarkuning, which was not submitted in writing only orally, to Cintamanik Village and Banjarwaru Village to the RT / RW. The research result showed the performance was disclosed to the community through year-end report, development, service and meeting activities. Submission of village fund risk was submitted in Sadeng Village to community, Muarajaya Village to TPK village, in Bantarkuning village related to corruption, Cintamanik Village submitted to TPK, village fund risk in Banjarwaru Village was still minimal delivered in 2015-2016, at Cileungsi Village delivered from stage planning up to accountability. The belief in the village government occurred in 6 villages in the research as a feedback from the village government's performance. Based on the findings of the researchers, Sadeng, Muarajaya and Cileungsi villages had a balance of power, duties and accountability. In the Bantarkuning village political element, in Cintamanik Village, the research result showed that there were double positions of village government with village BPD that were from 4 people, namely nurjali who served as chairman of BPD, Hapni secretary of BPD and cation program of Cintamanik Village government, kill member of BPD and kaurs Cintamanik Village 
Government's welfare, and sanosi namely the general caur and vice chairman of BPD (Village Regulation Cintamanik No. 141.1 / 1 / Year 2015). Conflicts of interest occurred in 5 villages related to the construction site, Sadeng village conflict had not occurred. The research results showed that 6 villages were willing to be graded by the community. The findings in the field are the involvement of Inspectorate, Local Village Assistant (PLD), village facilitator (PD) in Sadeng Village. In the village of Muarajaya the involvement of PD in the period of 1 week 1 time or 2 weeks 1 time, in the village of involvement of Bantarkuning PD 1 week 1 times. In Cintamanik Village there was PD involvement. In Banjarwaru village there was a new companion involvement implemented in 2016, in 2015 had not been implemented. The involvement of PD in Cileungsi village 2015 implemented by PNPM in 2016 was implemented by village counselors.

Based on the data of the research, related to the internal monitoring process implemented by the Inspectorate Bogor Regency Isnpektorat has fulfilled 4 dimensions in internal control namely the standard dimension of information that was the availability of information about the object of supervision. Based on the research data previously described, special surveillance of village funds was not implemented by the Bogor Inspectorate, the monitoring of village funds was included in the village government oversight activities in the Annual Working Program (PKPT). The availability of objectives of supervision that was based on research data that it was in accordance with the theory of objectives of supervision was to prevent acts deviation. Indindicators that had not been implemented in this dimension that Inspectorate Bogor Regency had no strategy in carrying out supervision. Related to the theory of control processes robbins and couter that dimension the process of performing the measurement was met but not yet optimal because the indicator about the organization of the conference was not implemented because based on the research data it was confidential. The availability of reports by the Bogor Inspectorate was a form of written supervision of the village government. Based on the research data, the dimension of the process of doing the comparison was fulfilled, the range of variation in the supervision process carried out by the Inspectorate of Bogor Regency was carried out in reference to the regulations mentioned in the research results. It aimed to ensure the achievement of the objectives as stipulated in law. The dimension of corrective action-making process was fulfilled by the inspectorate of Bogor Regency, that the steps taken if found the deviation as the result of the research that the Inspectorate gave recommendation in case of irregularities, other related activities this dimension in the Inspectorate that there were training activities provided to the village government, then the desire in increasing the number of auditor personnel, and supervision at the entry meeting. Factors affecting internal control by Inspectorate Bogor Regency that was based on the results of research, changes in the environment related to the organization of the village based on the results of research it is in accordance with the theory of monitoring factors munandar that organizational changes could affect the supervision conducted by the Inspectorate, other influencing factors were the complexity organization related principles prudence based on the results of research Inspectorate conduct crosscheck of information or complaint report, apparatus factor of government apparatus of village, mistake of government of village which observed from report of performance of government of village, and duty conducting inspection complicance by Inspectorate of Bogor Regency.

The discussion on external supervision was carried out using 3 concepts. In the first concept of transparency consisting of 4 dimensions of clarity, integration, accessibility, and logical rational. In the first dimension of clarity of information, based on research data clarity dimension fulfilled in 6 villages but not yet optimal because the implementation of transparency as supervision of information growing related to village funds still had some 
constraints such as in Sadeng Village and Cileungsi dimension clarity fulfilled, clarity of information still constrained in several villages related to this dimension that occured in the Village Muarajaya, Bantarkuning, Banjarwaru. In the second dimension of the concept of transparency is integration, this dimension was fulfilled in 5 namely Sadeng, Muarajaya, Bantarkuning, Cileungsi and Cintamanik but there were equations related to the distribution of electronic content had not been distributed to the public only representative by data through group messenger accessed by BPD and community leaders. Distribution of content did not occur in the Village of Banjarwaru. The third dimension was the accessibility dimension fulfilled in 6 villages that became the object of research. Based on the results of research in Sadeng, Muarajaya, Bantarkuning, Cintamanik, and Banjarwaru villages, public guarantee in receiving documents had not been implemented in all villages. In contrast to research data in Cileungsi Village that the community was guaranteed to receive documents through the village fund leaflets. The last dimension was logical / rational fulfilled in 6 villages but not yet optimally because the indicators of information clarity were still constrained in 6 villages. Based on Pan Suk Kim's theory of transparency concept, the clarity of information became important in implementing supervision because if the village government did not understand the information or BPD and the community did not understand the information would not occur supervision activities. Supervision using the concept of transparency was still weak because there were several factors that influenced the related research results that the availability of electronic content, not guaranteed the public received documents and clarity of information that was still not optimal, thus monitoring using the concept of transparency had not been optimally implemented in 6 villages.

External surveillance used the concept of participation consisting of 2 indicators according to Bryson namely community involvement in policy formulation and policy implementation. In the formulation of policies implemented in 6 villages through formal village forums namely MUSDES, MUSRENBANG, or informal meetings as the result of research data, however, the MUSDES or MUSRENBANG forum was a formal forum attended by representatives of the community, leaders, RT / RW leaders, religion leaders, etc. . Community involvement in Banjarwaru Village was still constrained by access. Implementation of village fund policies in 6 villages was implemented by the Implementing Team of Activities (TPK), based on field data that the implementation was representative. In Sadeng Village communities could be involved in self-help through the provision of consumption. In the village of Banjarwaru society could be involved but was still difficult based on research data. Based on these results supervision activities can be carried out by becoming a TPK village but it was only implemented by the representation of the citizens only. Associated with the participation of the arnstein community, the ladder of community participation that occurred in 6 villages is at the stage of placation because community involvement in policy formulation was available but implementation was only implemented by the representation of communities that were part of the organization, namely TPK. Community participation was an opportunity for people to have space to carry out supervision, the implementation of participation as a supervisory effort was not optimal because it is only implemented through the representation of citizens only. The importance of participation aimed to ensure democracy in the village.

Associated with the concept of accountability theory from LAN and BPKP referred to the research data that the dimensions of intentions disclosure fulfilled related benefits, fairness and fairness. Submitting this accountability as an accountability effort of the village government to the community in addition, it was a part of the implementation of the monitoring of village funds. The dimensions of directing mind were fulfilled in five villages: Sadeng, Muarajaya, Cintamanik, Banjarwaru, and Cileungsi which were carried out with 
accountability report but in Bantarkuning village this had not been implemented and only delivered through oral submission. Submission of reports through directing mind as a technique of carrying out supervision in writing. Document monitoring aimed to minimize administrative errors and crosscheck development efforts with reports or documents. In the dimension of performance visibility, this dimension was related to the achievement of performance to the community fulfilled in 6 villages based on the research result that was through the report and the realization of development. In the answering precaution taken dimension associated with the exposure of the risk of village funding on the basis of data on the results of research conducted, the delivery of information about the risks associated with the purpose of supervision as a preventive effort to prevent errors in the organization. On the dimensions of the governing body and citizen responsibility fulfilled on 6 villages as data research results in improving fairness and accountability. In the reciprocal accountability dimension based on research data, accountability submission is done at the end of the fiscal year in meeting activity or availability of access through report, availability of MUSRENBANG forum or reciprocal village meeting obtained based on data of trust to village government. The creation of accountability will encourage supervision of funds villages to be optimal, one of which is the emergence of public trust in the community due to the performance provided by the village government. The dimensions of the balance of power, duties and accountability in Sadeng Village, Muarajaya, Bantarkuning, and Cileungsi Village are implemented. In the data of research results in Cintamanik Village this dimension is not fulfilled because the double position of BPD with the village government, related to it that the implementation of supervision that should be implemented by BPD become not optimal.Pada Banjarwaru based on research data that in 2015-2016 has not been implemented because community representatives are appointed by the village government. expectations are undertaken related to obstacles implemented through the use of other funding sources, deliberation and socialization, coordination with BPD, provision of reports and monitoring to TPK. Accountability is still weak in some villages have an impact on the supervision that has not been optimal because of accountability is one of the concepts in carrying out supervision. In the corporate fairness dimension of conflict of interest occurred in 5 villages that are related to development sites in Muarajaya, Bantarkuning, Cintamanik, Banjarwaru, and Cileungsi.Pada Sadeng village conflict has not happened.Dimensi right roles on 6 village responsibilities related to the implementation of development and accommodate the development that has not been running in the next year. In the dimension of citizen action that is the active involvement of the community occurred in Muarajaya village since the presence of village funds. In Cintamanik Village communities can be involved in BPD involvement and involvement. The active involvement of the tentative community in Sadeng Village because it is influenced by individual desires, in the villages of Bantarkuning, Banjarwaru and Cileungsi is still minimal in 2015-2016. Based on this, the active involvement of the community has an impact related to accountability. The wage of abdications dimension is fulfilled in 6 villages by involvement in the identification of deviations, the opportunity to be involved as TPK, LPM or BPD, availability assessed by the community, and coordination efforts. In the last dimension, the dimension of validations of assertions refers to the results of field data, the majority of villages supported by the involvement of practitioner such as in Sadeng Village namely Inspectorate, local village counselor and village assistant, in Muarajaya Village, Bantarkuning, Cintamanik the involvement of village counselor, Banjarwaru village involvement of village counselors has not been implemented in 2016 alone, in 2015 has not been implemented. At Desa Cileungsi, the involvement of the village counseling practitioners in 2015 was carried out by former PNPM and village counselors in 2016. Based on these 
results, the involvement of researchers did not occur in all villages. The importance of the involvement of parties from the broad range of village organization environments aims to ensure accountability, besides the involvement of outsiders can function as village government supervisor.

\section{Conclusion}

The supervision process by the Inspectorate of Bogor Regency was not yet optimal because it was only carried out generally in the village government supervision activities through the Annual Working Program (PKPT) which was implemented for 5 rounds in one year. Special monitoring of village funds had not been implemented for 2015-2016. The monitoring process by APIP was conducted through community reports through community complaints services. Based on the findings in the field, APIP did not have a supervisory strategy, conference activities, and information in the form of statistics, the graph was not yet available only table. Supervision by the Inspectorate was carried out in the form of audit and audit. Factors affecting internal control were the changes of the village government structure, the village political element, the human resources of the village government apparatus, the quantity of Human Resources Inspectorate, and the area of supervision. The process of external monitoring of village funds referred to 3 concepts of transparency, participation and accountability not yet optimal. The weakness of external monitoring in the village was influenced by the understanding of village government officials regarding village fund information, the availability of information through electronic content that had not been distributed, the access of the public to receive the documents, the accountability was still weak and the active involvement in community participation was not optimal yet.

Capacity building of the village government apparatus was done through education activities by the Directorate General of Village Administration, Increasing public awareness on the importance of involvement of village fund monitoring by the Ministry of Village, Development of Underdeveloped Regions and Transmigration through socialization and publication, Supervision of village governance structure by strengthening the role of subdistrict head. Acceleration of the policy brief on the supervision of the sub-district against village funds by the Ministry of Home Affairs and the Ministry of Law and Human Rights, Improving the importance of enforcing the Public Information Disclosure Act by the Public Information Commission in the village by providing media information boards, ballot boxes and banners, knowledge from the village government apparatus to the new village government apparatus in the event of a change of village governance structure to ensure the education process runs at the village level with support from the Village and Community Empowerment Offices. To increase community oversight required the support of non-representative participation in village forums. Increased community participation could be done by building a sense of belonging from the village informal events such as soccer games, etc., Optimizing the role of community leaders in increasing community participation by providing input on the availability of media delivery of information to the village government. Creation of a democratic and democratic village head election climate free from the support of village institutions. Optimizing research on village funds as an agent of village fund monitoring because villages needed recommendations from those who had a qualified education. 


\section{References}

[1] A. Djaenuri, Hubungan Keuangan Pusat- Daerah : Elemen-elemen penting hubungan keuangan pusat-daerah. Jakarta: Ghalia Indonesia, 2012.

[2] H. A. W. Widjaja, "Otonomi Desa : Merupakan Otonomi yang Asli, Bulat dan Utuh," 2004.

[3] OJK, "Gambaran Umum Pembangunan Jawa Barat Potensi Pendanaan Pembangunan Infrastruktur Strategis Jawa Barat." 2015.

[4] BPMPD, "Menteri Marwan Apresiasi Penyerapan Dana Desa di Kabupaten Bogo." 2015.

[5] R. W. Griffin, Head. Manajemen. Jakarta: Erlangga, 2004.

[6] S. P. Robbins and M. Coulter, Management. New Jersey: Pearson Education International.

[7] Munandar and M. Budgeting, Perencanaan Kerja Pengkoodinasian Kerja. Pengawasan Kerja, 1st ed. Yogyakarta: BPFE Universitas Gajah Mada, 2001.

[8] Komarudin and S. Yudo., "Transparansi dan akuntabilitas pelayanan publik kasus teknologi pengelolaan air bersih dan air limbah domestik.” Jakarta, 2009.

[9] K. S. Quick and J. Bryson., Theories of public participation in governance. Edward Elgar, 2016.

[10] S. R. Arnstein, "A ladder of Citizen Participation," J. Am. Plan. Assoc. (JAIP). London UK, 1969.

[11] BPKP, Akuntabilitas. Tim Studi: AKIP, 2001.

[12] W. L. Neuman, Basics of Social Research Methods: Qualitative and Quantitative Approaches, 2nd ed. Boston: Allyn and Bacon, 2007.

[13] S. Arikunto, Prosedur penelitian suatu pendekatan praktik. Jakarta: Rineka Cipta, 2010.

[14] W. L. Neuman, Social research methods: qualitative and quantitative approaches. Boston: Allyn and Bacon, 1994. 